\title{
Anticompetitive Social Norms as Antitrust Violations
}

\author{
Dean Harvey $\dagger$
}

\section{INTRODUCTION}

The antitrust laws broadly forbid agreements in restraint of trade. These illegal agreements are typically imagined as products of smokefilled backroom discussions, where titans of industry set prices over cigars and whiskey. ${ }^{1}$ Such clear examples form the inner core of what section 1 of the Sherman Act proscribes, ${ }^{2}$ but the outer boundaries of section 1 liability are unclear and are the subject of substantial disagreement among courts and academics.

For instance, imagine an isolated town with two gas stations located across the street from each other, each charging $\$ 2.00$ per gallon of gasoline. One morning, the owner of the first station increases her prices by $\$ 0.25$, even though her cost of selling gasoline remains unchanged. This first owner knows that, assuming the second owner does not change his prices, customers will likely abandon her station and opt for the cheaper gasoline of her competitor. However, she also knows that, if the second owner likewise increascs his prices by $\$ 0.25$, each owner will sell the same amount of gasoline at the higher price, and they will therefore both enjoy higher profits. The second owner notices the increase in price and increases his price to match. Has a price-fixing conspiracy occurred in violation of section 1 of the Sherman Act? ? Theoretically, yes. Both have "agreed" to raise their price above the competitive level. But as a practical matter, both are likely to get away with it, insofar as there is no further evidence of an

Copyright $@ 2006$ California Law Review, Inc. California Law Review, Inc. (CLR) is a California nonprofit corporation. CLR and the authors are solely responsible for the content of their publications.

$\dagger \quad$ J.D. Candidate, May 2006, School of Law, University of California, Berkeley (Boalt Hall). I primarily thank Dan Rubinfield and participants of his seminar on Antitrust Law and Economics for thoughtful comments and questions. This Comment has also benefited from discussions with Shawn Bayern, Allen Grunes, Howard Shelanski, Maurice Stucke, and Tina Wong. An earlier version of this paper received the 2005 William E. Swope Antitrust Prize, sponsored by Jones Day. I am tremendously grateful for their generosity and hospitality.

1. See, e.g., Kurt Eichenwald, The Informant (2000) (describing a conspiracy to fix the price of lysine).

2. 15 U.S.C $\$ 1(2000)$.

3. I thank Aaron Edlin for this example. 
agreement, such as a phone call, a letter, or evidence of industry-imposed punishments for violating the terms of the conspiracy.

This Comment explores a similar question: when the operation of a social norm is, on the whole, anticompetitive, are the participants of the norm guilty of violating section 1 ? For example, imagine a group of wholesalers who sell a unique and valuable type of lumber to retailers. They enjoy an oligopoly over sale of the raw material. Now suppose some retailers begin to enter the wholesale market, threatening to compete with the wholesalers. Wholesalers may develop a norm of refusing to deal with retailers who also engage in wholesaling. They may develop pejorative terms for such retailers and treat them as pariahs. Moreover, when the occasional wholesaler violates the norm and sells to retailers who also engage in wholesaling, that intrepid wholesaler-whose actions make the market more competitive-may be sanctioned by other wholesalers until the behavior stops and the entrepreneurial wholesaler conforms to the norm. These sanctions may take the form of financial penalties or may simply amount to insulting phone calls. In contrast to the gas station owners in the previous example, the wholesalers may be completely unaware of the anticompetitive effects of their behavior.

Are the wholesalers who participate in the norm guilty of violating section 1? This Comment argues that they are-that participants in anticompetitive social norms do indeed violate the antitrust laws. This argument has two main implications. First, anticompetitive social norms may flourish in market structures normally thought largely immune from collusion. Specifically, robust, anticompetitive norms may thrive in markets with low entry barriers and low concentration levels. That collusion can be effective under these conditions has important implications for antitrust enforcement and liability, especially in the context of mergers. Second, the argument challenges conventional treatments of social norms. Many law and economics scholars too often characterize social norms as efficient, welfare-optimizing mechanisms, ignoring or downplaying their potential to benefit a small group to the detriment of society as a whole. ${ }^{4}$

Part I of this Comment summarizes a typical section 1 case and the current case law relevant to inferring an agreement under section 1. Part II briefly reviews the history of the economics of collusion and its interaction with antitrust law. Part III discusses social-norm research and mechanisms of community enforcement. Part IV presents a case study of NASDAQ market makers and their "quoting norm," which had profound anticompetitive effects in a market structure with low concentration levels and low

4. This is not to say that no legal scholars have recognized the potential harmful effects of social norms. See, for example, David Charny, Illusions of a Spontaneous Order: "Norms" in Contractual Relationships, 144 U. PA. L. Rev. 1841, 1848 (1996) and Geoffrey P. Miller, Norms and Interests, 32 Hofstra L. Rev. 637 (2003). 
entry barriers. The case study also describes an enforcement mechanism underestimated by industrial organization economists-namely, social sanctioning. Finally, Part V examines the implications of viewing social norms as antitrust violations on antitrust liability and enforcement, with particular attention to horizontal merger review.

\section{Agreements Under Section I of the Sherman Act}

Section 1 of the Sherman Act prohibits contracts, combinations, and conspiracies in restraint of trade. ${ }^{5}$ Contracts, combinations, and conspiracies refer to the same concept-agreement. Courts may infer agreement from business acts, ${ }^{6}$ even if no formal agreement is alleged to have taken place. ${ }^{7}$ Explicit mutual assurances are not required ${ }^{8}$ Section 1 agreements may be either spoken or unspoken. ${ }^{9}$ Spoken agreements consist of a meeting of minds resulting from some form of communication; ${ }^{10}$ this is a broad category, including "knowing wink[s]"11 and "grunts." 12 Unspoken agreements, on the other hand, result only from acts occurring in the marketplace. ${ }^{13}$

If a court finds that there is an agreement to restrain trade, its next question is whether that restraint is reasonable. To determine reasonableness, courts look to whether the behavior is, on balance, procompetitive or anticompetitive. ${ }^{14}$ The extent of the analysis varies depending upon the conduct and quality of the defendant's business justification for the agreement in question. ${ }^{15} \mathrm{~A}$ court will first examine the behavior itself and ask if it has a significant anticompetitive effect. Initial concerns include whether the behavior is inherently unreasonable, or if it is of a type that courts have

5. 15 U.S.C. $\$ 1$; see also 6 Phillip E. Areeda \& Herbert HovenKamp, Antitrust Law $1400 \mathrm{a}$, at 1 (2d ed. 2003).

6. See, e.g., E. States Retail Lumber Dealers' Ass'n v. United States, 234 U.S. 600, 608-09 (1914) (holding that retailers violated the Sherman Act by circulating a blacklist naming wholesalers who sold directly to customers, with the "evident purpose" of encouraging recipients of the blacklist to reduce their dealings with the blacklisted firms).

7. See Am. Tobacco Co. v. United States, 328 U.S. 781, 809 (1946); Theatre Enters., lnc. v. Paramount Filın Distrib. Corp., 346 U.S. 537, 540 (1954).

8. See 6 AREEDA \& HovenKAMP, supra note 5, 1404, at 18-20.

9. See Gregory Werden, Economic Evidence on the Existence of Collusion: Reconciling Antitrust Law with Oligopoly Theory, 71 ANTITRUST L.J. 719, 735-36 (2004).

10. Id. at 735 .

11. Esco Corp. v. United States, 340 F.2d 1000, 1007 (9th Cir. 1965).

12. Isaksen v. Vermont Castings, Inc., 825 F.2d 1158, 1164 (7th Cir. 1987).

13. Werden, supra note 9 , at 735-36.

14. Chicago Bd. of Trade v. United States, 246 U.S. 231, 238 (1918) ("The true test of legality is whether the restraint imposed is such as merely regulates and perhaps thereby promotes competition or whether it is such as may suppress or even destroy competition.")

15. See John J. Flynn, Rethinking Sherman Act Section l Analysis: Three Proposals for Reducing the Chaos, 49 Antitrust L.J. 1593, 1610-11 (1980). 
previously encountered, such as price-fixing ${ }^{16}$ and territorial division. ${ }^{17}$ If the behavior has significant anticompetitive effects, a court is likely to deem the behavior illegal per se, especially if the practice is unnecessary to achieve a compelling, procompetitive purpose.

If the court characterizes the conduct as inherently unreasonable, it may presume the conduct to be anticompetitive, and the alleged offender

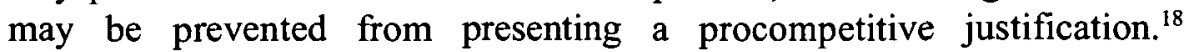
However if the conduct merits closer examination, the court may apply an abbreviated "quick look" analysis. ${ }^{19}$ The plaintiff may rebut the defendant's justification and argue that there was a reasonable, less restrictive alternative to the conduct in question. However, if there is no sensible justification, or if there is a less restrictive alternative, the conduct is a naked restraint of trade and probably a per se violation. Though no market analysis is required, the analysis leading to an outcome of per se illegality cannot be too cursory. ${ }^{20}$

If the defendant's justification is sufficiently sensible so that a presumption of anticompetitive effects is inappropriate, then a court will require a full "rule of reason" analysis. ${ }^{21}$ Under such an analysis, the plaintiff first must show and quantify the anticompetitive effects. Unless the anticompetitive effects are substantial and clear, ${ }^{22}$ this showing will include a market-power analysis, requiring a market definition and an economic analysis demonstrating relevant market shares. ${ }^{23}$ The defendant must refute the plaintiff's claims by explaining and quantifying any procompetitive effects. The defendant is liable if the conduct is, on balance, anticompetitive, or if there is a less restraining reasonable alternative. ${ }^{24}$

In Eastern States Retail Lumber Dealers' Ass'n v. United States, an early section 1 case, lumber wholesalers decided to sell directly to

16. See, e.g., United States v. Socony-Vacuum Oil Co., 310 U.S. 150, 225 (1940).

17. See, e.g., United States v. Topco Assocs., lnc., 405 U.S. 596 (1972).

18. Arizona v. Maricopa County Med. Society, 457 U.S. 332, 343-48 (1982) (holding that certain restraints on competition, including price-fixing agreements, are unlawful per se, and no justification may be interposed as a defense). But see Broad. Music, lnc. v. CBS, 441 U.S. 1 (1979) (holding that a compelling procompetitive justification may justify even literal price fixing).

19. California Dental Ass'n v. FTC, 526 U.S. 756, 770 (1999) (holding that a truncated or "quick-look" analysis may be appropriate when "an observer with even a rudimentary understanding of economics could conclude that the arrangements in question would have an anticompetitive effect on customers and markets").

20. See id. at 771-73 (requiring that quick-look analysis involve "more than cursory treatment" when there is a compelling procompetitive justification or when the anticompetitive effects of the conduct are unclear).

21. See Chicago Bd. of Trade v. United States, 246 U.S. 231 (1918).

22. FTC v. Indiana Fed'n of Dentists, 476 U.S. 447 (1986).

23. See, e.g., United Statcs v. Gcneral Dynamics Corp., 415 U.S. 486 (1974) (performing a detailed market-share analysis).

24. See generally, Phillip Areeda, A Second Century of the Rule of Reason, 59 AnTIrrust L. J. 143 (1990). 
consumers rather than to traditional retail intermediaries. ${ }^{25}$ These intermediate retailers in turn circulated among themselves blacklists naming wholesalers who sold directly to consumers, causing many retailers to boycott the blacklisted wholesalers. ${ }^{26}$ The Supreme Court inferred an agreement among retailers to boycott the wholesalers, based on (1) circulation of the blacklist and (2) the resulting "appreciably impaired" reduction in business of the blacklisted wholesalers. ${ }^{27}$

Later, in American Column \& Lumber Co. v. United States, a hardwood trade association circulated detailed information about prices, production, and inventories, and it held meetings where members explicitly advocated limiting production. ${ }^{28}$ The Court acknowledged the potential of social norms to maintain anticompetitive conduct, stating that the competitors relied "for maintenance of concerted action" on the "potent and dependable restraints . . of business honor and social penalties." ${ }^{29}$ Because large price increases followed with no evident basis in normal market forces, the Court found that the agreement violated section $1 .^{30}$

Interstate Circuit, Inc. v. United States was the first case to examine tacit collusion. ${ }^{31}$ First-run motion picture exhibitors asked individual motion picture distributors to impose restrictions on second-run exhibitors. ${ }^{32}$ The distributors then imposed identical restrictions on the second-run theaters. ${ }^{33}$ The court found an agreement between the distributors to impose the same restrictions despite no explicit evidence of a conspiracy. ${ }^{34}$ The Court held that "[i]t was enough that, knowing that concerted action was contemplated and invited, the distributors gave their adherence to the scheme and participated in it." 35 The Court inferred agreement based on conscious, parallel, interdependent action. Interdependent refers to situations where concerted action is in the best financial interest of the individual actor only if others participate in the behavior. That is, action is interdependent when it would be unprofitable but for the parallel behavior. The two cases that came closest to inferring an agreement solely from parallel conduct are United States v. Paramount Pictures ${ }^{36}$ and American

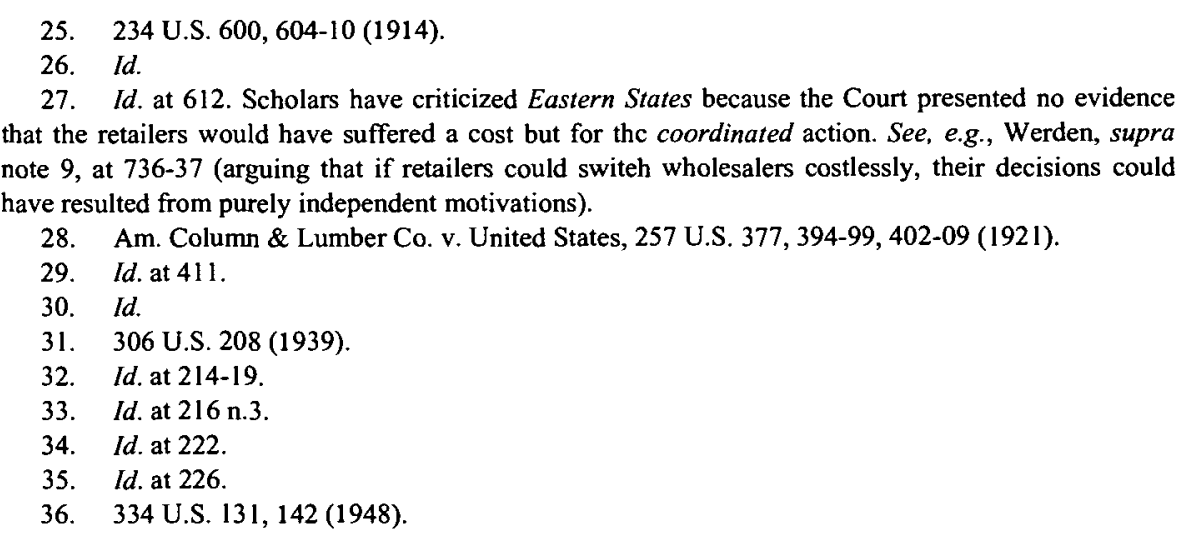


Tobacco Co. v. United States. ${ }^{37}$ These cases prompted Edward Levi to argue that parallel action had become a substitute for agreement under section $1{ }^{38}$ The legal doctrine of conseious parallelism arose out of these cases. ${ }^{39}$

However, parallel business behavior is not of itself sufficient to show an agreement under section $1 .^{40}$ Though business behavior is normally admissible in inferring an agreement, ${ }^{41}$ if the behavior may be explained as the result of rational, independent action, then that behavior cannot be used as evidence for an anticompetitive agreement. ${ }^{42}$ The Supreme Court made clear that mere parallelism was insufficient in Theatre Enterprises $v$. Paramount Film Distributing Corp. ${ }^{43}$ when it commented that "[c]ircumstantial evidence of consciously parallel behavior may have made heavy inroads into the traditional judicial attitude toward conspiracy; but 'conscious parallelism' has not yet read conspiracy out of the Sherman Act entirely." ${ }^{\circ 4}$ Though business behavior is admissible circumstantial evidence from which a fact finder may infer an agreement, parallel behavior, of itself, is insufficient.

Later in Matsushita Electric Industrial Co. v. Zenith Radio Corp., the Court added that in order to infer an agreement, the conspiracy must be in the economic self-interest of the conspirators, and the evidence must show that the conspirators were not acting independently. ${ }^{45}$ To overcome a summary judgment motion, a plaintiff "must present evidence "that tends to exclude the possibility' that the alleged conspirators acted independently." ${ }^{\prime 46}$ Commentators have criticized this language because it conflicts with the civil preponderance of the evidence standard. ${ }^{47}$

\footnotetext{
37. 328 U.S. $781,800-08$ (1946).

38. Edward H. Levi, The Antitrust Laws and Monopoly, 14 U. CHI. L. REv. 153, 177-78 (1947).

39. Michael Conant, Consciously Parallel Action in Restraint of Trade, 38 MinN. L. REv. 797, 797 (1954).

40. Theatre Enters., Inc. v. Paramount Film Distrib. Corp., 346 U.S. 537, 541 (1954).

41. Id. at 540; Am. Tobacco Co. v. United States, 328 U.S. 781, 809 (1946).

42. Monsanto Co. v. Spray-Rite Serv. Corp., 465 U.S. 752, 764 (1984).

43. 346 U.S. at 541 .

44. Id.

45. 475 U.S. 574 (1986); see also E.1. du Pont de Nemours \& Co. v. FTC, 729 F.2d 128 (1984). The requirement of economic self-interest has been the target of much criticism and perhaps contradicted by the Court itself. See Robert L. Hubbard, Grunts, Winks, \& Nods: What Meets the Agreement Element of a Section I Claim?, 5 SEDONA CONF. J. 99, 101-02 (2004) (arguing that "Section 1 does not require the defendant to profit. Murder, jay-walking, and pollution need not be profitable (or even economically rational) to be illegal, and neither should unreasonable restraints on trade." Furthermore, "[s]ix years later in Image Technical, the Court deelared that an economic theory that 'does not explain the actual market behavior revealed in the record' should be rejected.") (citing Eastman Kodak Co. v. Image Technical Services, Inc., 504 U.S. 451 (1992)).

46. Matsushita, 475 U.S. at 588 (quoting Monsanto, 465 U.S. at 764).

47. See Werden, supra note 9, at 753 ('[P]laintiffs' burden is better stated as producing evidence not merely consistent with the existence of an agreement, but that 'would allow a reasonable finder of fact to conclude ... that the alleged conspiracy is more probable than not.") (quoting 2 AREEDA, Hovenkamp \& Blair, supra note 5, ๆ 308c, at 87); Richard Posner, ANTitrust Law 90, 99-100 (2d
} 
Most recently, the Supreme Court in Brooke Group Ltd. v. Brown \& Williamson Tobacco Corp. stated that "tacit collusion, sometimes called oligopolistic price coordination or conscious parallelism, describes the process, not in itself unlawful, by which firms in a concentrated market might in effect share monopoly power, setting their prices at a profitmaximizing, supracompetitive level by recognizing their shared economic interests and their interdependence with respect to price and output decisions." 48 Some scholars believe this interpretation shelters actors who recognize their interdependence and knowingly coordinate to establish supercompetitive prices without reaching an explicit agreement. ${ }^{49}$

To show an agreement, it is now clear that plaintiffs must demonstrate more than parallel business conduct by introducing additional evidence of a meeting of minds. For a fact finder to infer a conspiracy, the plaintiff must show that at least onc of six "plus factors" exists in addition to the parallel behavior. ${ }^{50}$ One type of plus factor exists if the parallel behavior constitutes an inexplicable coincidence, as seen in American Tobacco ${ }^{51}$ and Interstate Circuit. $^{52}$ A second type of plus factor occurs where the parallel conduct is a significant departure from previous behavior. The third type, perhaps the most crucial for our purposes, is parallel behavior that would be unprofitable for each participant but for the parallel conduct of all. Courts often use the language of "acts contrary to self-interest," 53 but this phrase is overbroad and confusing. Both independent and interdependent action may be in an actor's eeonomic self-interest. What matters is whether any defendant had an incentive to deviate from the parallel behavior assuming the other defendants would not deviate-that is, an incentive to defect from the

ed. 2001); Hubbard, supra note 45, at 100-01 (arguing that Matsushita's holding should be limited to instances where collusive behavior is economically irrational).

48. 509 U.S. 209, 227 (1993).

49. See Werden, supra note 9, at 764-65. Courts often analogize this to section 2 of the Sherman Act, under which monopoly pricing is legal. Id. at 767-68; see also, e.g., Verizon Communications, Inc. v. Law Offices of Curtis V. Trinko, 540 U.S. 398 (2004) (finding that a plaintiff who alleged breach of duty to share a network with competitors did not state a monopolization claim under section 2).

50. See Plywood Antitrust Litig., 655 F.2d 627, 633 (5th Cir. 1981), cert. dismissed, 462 U.S. 1125 (1983). The term "plus factors" originates in a Ninth Circuit decision regarding price-fixing. See Werden, supra note 9, at 745 (citing C-O-Two Fire Equip. Co. v. United States, 197 F.2d 489 (9th Cir. 1952)).

51. Am. Tobacco Co. v. United States, 328 U.S. 781, 789-804 (1946) (finding that precisely parallel price incrcases during a period of decreasing production costs and likely reductions in demand was inexplicable without collusion).

52. Interstate Circuit, Inc. v. United States, 306 U.S. 208, 221-27 (1939) ("substantial unanimity of action ... involv[ing] a radical departure from ... previous business practices" was a factor in inferring an agreement).

53. See, e.g., Williamson Oil Co. v. Philip Morris USA, 346 F.3d 1287, 1310 (11 th Cir. 2003) ("It is firmly established that actions that are contrary to an actor's economic interest constitute a plus factor that is sufficient to satisfy a price fixing plaintiff's burden in opposing a summary judgment motion."). 
purported agreement. ${ }^{54}$ The fourth plus factor depends on whether there is an opportunity for agreement. Opportunities to agree are thought to increase with market concentration, the homogeneity of the relevant products, and the ability of firms to monitor other firms' behavior and punish defection from a collusive arrangement. ${ }^{55}$ Fifth, courts consider whether there is a market explanation for price increases. ${ }^{56}$ What unites these plus factors is an overarching concern with discovering extra pieces of evidence that make collusion more likely.

Courts substantially rely upon evolving economic theory to discern whether there is an agreement under section 1 of the Sherman Act. The next Part summarizes relevant developments in the economics of collusion.

II

\section{THE ECONOMICS OF COLLUSION}

Antitrust law now firmly rests on a foundation of economics, ${ }^{57}$ so reviewing the changing and controversial economic theories of collusion will aid our understanding of the outer boundarics of what conduct violates section 1 .

Most work on collusion focuses on oligopolistic competition-that is, competition in a market dominated by few sellers. Oligopoly theory began with the Cournot model in $1838 .^{58}$ In its most simplified form, oligopolistic Cournot competition occurs with a single, homogenous product. A single firm sets its price and production quantity to the monopoly level, and as the number of competitors increases, prices decline and quantities increase toward perfectly competitive levels. ${ }^{59}$ Nearly a century later, Edward Chamberlin argued instead that in markets with few sellers and fairly homogenous goods, we should expect prices to be set to near-monopoly levels. ${ }^{60}$ Because of this allegedly natural tendency toward supercompetitive prices in concentrated markets, Chamberlin argued against inferring agreement among oligopolists simply because there is parallel pricing above competitive levels. ${ }^{61}$

William Fellner later argued that firms may easily coordinate on supercompetitive prices though explicit bargaining. ${ }^{62}$ Though Fellner agreed

54. See Eric Rasmusen, Games and Information: An Introduction to Game Theory 23 (2001).

55. See id.

56. See, e.g., 328 U.S. at 789-804.

57. See generally POSNER, supra note 47.

58. See Antoine Augustin Cournot, Researches into the Mathematical Principles of THE THEORY OF WeALTh (Nathaniel T. Bacon trans., A.M. Kelley 1971) (1838).

59. Id.

60. Edward H. Chamberlin, Duopoly: Value Where Sellers Are Few, 44 Q.J. Econ. 63, 83-84 (1929).

6I. Id. at 65 .

62. William Fellner, Competition Among the Few 130-33 (1949). 
with Chamberlin that coordination was easy to achieve, Fellner focused on active negotiation between firms, whereas Chamberlin argued that coordination arose from natural market forces. ${ }^{63}$ Factors such as differing cost structures and product heterogeneity decrease the ability of competitors to coordinate on price without overt communication. ${ }^{64}$ Fellner also came to the same conclusion regarding antitrust policy as Chamberlain: that coordination is so easy to achieve it would be almost futile to try to prevent it. ${ }^{65}$

In an influential subsequent article, Donald Turner concluded that tacit, or unspoken, agreements should not violate the antitrust laws. ${ }^{66} \mathrm{He}$ agreed with Chamberlin that under the strict conditions of Chamberlin's theory of oligopoly, a concentrated market will maintain prices at monopoly levels without bargaining or agreement between the parties. ${ }^{67}$ But reality presents sufficient impediments to successful coordination, and if firms coordinate on near-monopoly prices in an actual market, some form of agreement is likely responsible. ${ }^{68}$

Because supercompetitive pricing is in the interest of the firms that participate in it as a group, early scholars inferred that it would also be in the interest of every individual firm. But this view commits the fallacy of division; that is, it assumes that what is in the interest of the group is also in the interest of each member. As the influence of game theory grew, economists began to doubt the ease with which firms might coordinate on price. In 1964, George Stigler applied the lessons of non-cooperative games-such as the prisoner's dilemma ${ }^{69}$ - to show that firms had incentives to defect from a cooperative price-fixing scheme by lowering their prices slightly below prevailing levels. ${ }^{70}$ If a firm secretly reduces its prices to just below that of its competitors, it may attract sufficient business away from other colluding firms to make more profit than if it adhered to the coordinative scheme. ${ }^{71}$ The ability of competitors to maintain supercompetitive prices, then, would depend upon their ability to detect and punish defectors. ${ }^{72}$ As the number of competitors decreases, the likelihood of

\footnotetext{
63. Id.

64. Id.

65. Id. at 309-10.

66. Donald F. Turner, The Definition of Agreement Under the Sherman Act:Conscious Parallelism and Refusals to Deal, 75 HARv. L. Rev. 655, 671 (1962).

67. Id. at 663-64.

68. Id. at 664 .

69. For an explanation of the prisoner's dilemma, see, for example, Thomas C. Schelling, Micromotives AND MACROBEHA VIOR 110-11, 231, 216-17 (1978).

70. See George J. Stigler, $A$ Theory of Oligopoly, 72 J. PoL. ECoN. 44 (1964).

71. Id. at 46 .

72. See id.
} 
coordination increases, because it becomcs easier to identify and punish defection. ${ }^{73}$

More recently, as empirical studies have tested game theory analyses, experimental economists, echoing the theories of Chamberlin and Fellner, have shown that people cooperate much more than game theory supposes. ${ }^{74}$ Cooperation rates rise when individuals face the same incentives and when they are part of the same social group. ${ }^{75}$ Collusion becomes more likely with fewer firms and with a greater possibility of direct punishment. ${ }^{76}$ The effects of non-binding communication ("cheap talk") are largely uncertain, but "the effect is greatest with posted prices and differentiated products." That is, communication between actors facilitates collusion most when all players perceive the communication publicly (everyone knows that everyone knows) and when differences in product quality cause differences in prices. Indeed, some have suggested that since these studies use subjects who are strangers to each other, the studies may significantly underpredict the ability of individuals who are familiar with one another to cooperate. ${ }^{78}$

Industrial organization economists now generally argue that four factors are necessary to establish an effective collusive arrangement. First, a group of colluders must be powerful enough to profitably raise the market price above competitive levels. ${ }^{79}$ The constraints facing a collusive group, or cartel, are familiar to a monopoly analysis: the market power of a cartel derives from the elasticity of the demand curve it faces, and this elasticity incorporates the other firms' ability to enter the market and the availability to purchasers of substitutes ${ }^{80}$ Second, members of a cartel must place a sufficiently low probability on being caught and assign a sufficicntly low cost to being caught. ${ }^{81}$ Third, the costs of organizing the cartel must be

73. This is so, Stigler argued, because firms in concentrated markets will more easily notice unexpected drops in business and attribute that to a defecting competitor than firms in unconcentrated markets. Id. at $48-56$.

74. See, e.g., Joyce Berg, John Dickhaut \& Kevin McCabe, Trust, Reciprocity, and Social History, 10 Games \& ECon. Behav. 122 (1995). Berg et al. describe an experimental "trust game" whercby player one may donate some amount of her endowment to player two in the hope that player two, who will then get twice player one's donation, will return to player one at least as much as was donated. Game theory predicts that both players will refuse to donate anything to each other. Berg et al. find, however, that player one will donate money to player two $94 \%$ of the time, and player two will return money to player one in a majority of cases. $I d$.

75. Charles A. Holt, Industrial Organization: A Survey of Laboratory Research, in THE HandBooK of ExPERIMENTAL EConomics 349, 402-03 (John H. Kagel \& Alvin E. Roth eds., 1995).

76. Id. at 406-09.

77. Id, at 411 .

78. See, e.g., Erin Ann O'Hara \& Claire Hill, A Cognitive Theory of Trust, WASH. U. L. Q. (forthcoming 2006); see also Russell Hardin, Conceptions and Explanations of Trust, in TRUST IN SOCIETY 3 (Karen S. Cook ed., 2001).

79. Dennis W. Carlton \& Jeffrey M. Perloff, Modern Industrial Organization 131 (4th ed. 2005).

80. Id.

81. Id. 
sufficiently low. ${ }^{82}$ Elements that decrease organizational costs may include a small cartel, ${ }^{83}$ a highly concentrated market, a homogenous product, and the existence of a trade association. ${ }^{84}$ Finally, cheating must be detectable and punishable. It is generally thought that cheating is easier to detect and punish where the number of firms is low, prices are relatively constant, and products are homogenous and sold at the same location in the distribution chain. $^{85}$

III

\section{SOCIAL NORMS AND COLLUSION}

This Section argues that social norms often have the structure of agreements for section 1 purposes; as a result, participants run afoul of the antitrust laws when a norm has an anticompetitive effect on the whole. This Section first summarizes research on social norms and then explains how social norms can qualify as agreements under section 1 .

\section{A. Research on Social Norms}

Research on social norms among law-and-economics scholars investigates how and when individuals adhere to social rules. Much of the literature's discussion of social norms focuses on their potential to be efficicnt, ${ }^{86}$ rather than investigating norms' possible negative consequences. ${ }^{87}$ None to my knowledge have investigated the potential of social norms to violate the antitrust laws.

There is no consensus about the definition of "social norm" in the law-and-economics literature. ${ }^{88}$ In this Comment, I will use Richard

82. Id. at 134 .

83. Among Department of Justice [hereinafter DOJ] price-fixing cases between 1963 and 1972 , the median number of co-conspirators, excluding large outliers, was 7.25. George A. Hay \& Daniel Kelley, An Empirical Survey of Price Fixing Conspiracies, 17 J. L. \& EcoN. 13, 20 (1974).

84. Id. at 21, 27; Carlton \& Perlof, supra note 79, at 136.

85. Carlton \& Perlof, supra note 79, at 136.

86. See, e.g., Robert C. Ellickson, Order Without Law; How Neighbors Settle Disputes (1991).

87. But see POSNER, supra note 47 (examining the role of social norms in racc discrimination and nationalism); see also sourccs cited supra note 4

88. See Kaushik Basu, Social Norms and the Law, in The New Palgrave Dictionary of ECONOMICS AND THE LAW 476, 476 (Pcter Newman ed., 1998). The following survey of definitions is illustrative:

Scholars offer a variety of definitions of the term "norms." See, e.g., Robert D. Cooter, Decentralized Law for a Complex Economy: The Structural Approach to Adjudicating the New Law Merchant, 144 U. PA. L. Rev. 1643, 1656-57 (1996) (defining norms as obligations); Melvin A. Eisenberg, Corporate Law and Social Norms, 99 CoLUM. L. Rev. 1253, 1255 (1999) (defining norms as "all rules and regularities concerning human conduct, other than legal rules and organizational rules");... . Eric A. Posner, Law, Economics, and Inefficient Norms, 144 U. PA. L. REv. 1697, 1699-1701 (1996) (defining norms as rules that distinguish desirable and undesirable behavior while giving a third party the authority to punish those engaging in undesirable behavior); Lior J. Strahilevitz, Social Norms from Close-Knit Groups to Loose-Knit Groups, 70 U. CHI. L. REv. 359, 363 n.24 (defining norms 
McAdams's definition: a social norm is an "informal social regularit[y] that individuals feel obligated to follow because of an internalized sense of duty, because of a fear of external non-legal sanctions, or both." Michihiro Kandori classifies these nonlegal enforcement mechanisms into personally enforced and community enforced norms. ${ }^{90}$ With personally enforced norms, the victim punishes the defector for violations. In repeated games between few players, a player who reneges on an obligation might be punished severely by his counterpart in a future round. ${ }^{91}$ With community enforeed norms, by contrast, the punisher will be another member of the community whom the norm violator may not have directly harmed. Moreover, another community member who witnesses the offending conduct and chooses not to punish the violator herself risks punishment by other community members. ${ }^{92}$ George Akerlof has argued that norms that are costly for individuals to follow may persist out of fear of social sanctions in the form of reputational harm..$^{93}$ How group members sustain cooperation is a large research agenda ${ }^{94}$ and is familiar to many disciplines. ${ }^{95}$

\section{B. Applying Section 1: Social Norms as Implicit Agreements}

At the outset, it is important to distinguish between social norms that simply facilitate antitrust violations and those that themselves are antitrust violations. This paper focuses on the latter. To review, firms run afoul of section 1 of the Sherman Act when they agree to conduct that is, on the

as "behavioral regularities that arise when humans are interacting with each other, regardless of whether that interaction is face-to-face"); Cass R. Sunstein, Social Norms and Social Roles, 96 Colum. L. REv. 903, 914 (1996) (using a rough definition of norms as "social attitudes of approval and disapproval, specifying what ought to be done and what ought not to be done").

Amitai Aviram, Regulation by Networks, 2003 BYU L. Rev. 1179,1181 n.4 (2003).

89. Richard H. McAdams, The Origin, Development, and Regulation of Norms, 96 MicH. L. REV. 338, 340 (1997).

90. Michihiro Kandori, Social Norms and Community Enforcement, 59 Rev. Econ. STud. 63 (1992).

91. See, e.g., Robert Axelrod \& William D. Hamilton, The Evolution of Cooperation, 211 Scl. 1390 (1981).

92. See generally Jonathan Bendor \& Dilip Mookherjee, Norms, Third-Party Sanctions, and Cooperation, 6 J. L. ECON. ORg. 33 (1990).

93. George A. Akerlof, A Theory of Social Custom, of Which Unemployment May Be One Consequence, 94 Q. J. ECoN. 749 (1980).

94. Some more interesting contributions include Daniel G. Arce M., Stability Criteria for Social Norms with Applications to the Prisoner's Dilemma, 38 J. Conflict Res. 749 (1994) (describing stability criteria for social norms that permit cooperation in repeated prisoner's dilemma situations); Diana Richards, Reciprocity and Shared Knowledge Structures in the Prisoner's Dilemma Game, $45 \mathrm{~J}$. CONFLICT RES. 621 (2001) (arguing that shared knowledge solves the coordination problem of choosing between strategies in the infinitely repeated prisoner's dilemma).

95. See, e.g., Robert Axelrod, The Evolution of Cooperation (1984) (political science); David Hirshleifer and Eric Rasmusen, Cooperation in a Repeated Prisoner's Dilemma with Ostracism, 12 J. Econ. Behav. \& Org. 87 (1989) (economics); Edna Ullmann-Margalit, The Emergence of Norms (1977) (sociology). 
whole, anticompetitive. When there is no explicit agreement, or insufficient circumstantial evidence from which to infer an explicit agreement, courts may infer that an implicit agreement exists if it finds collusive behavior with plus factors.

Social norms may fulfill the ordinary requirements for a section 1 agreement. Individuals may participate in social norms in part because of an expectation that others will also participate. ${ }^{96}$ Consider a market interaction between norm participants that is fundamentally a prisoner's dilemma; that is, suppose that without coordination, the participants could not reach a mutually beneficial equilibrium. If a social norm serves to coordinate the participants' action and thereby to solve the prisoner's dilemma, then the norm satisfies the crucial third plus factor: ${ }^{97}$ participation would be unprofitable but for the similar conduct of other participants.

In single-round market interactions, participating in such social norms would work against each participant's self-interest. (More technically, conforming to such a norm will not be a Nash equilibrium in a single-stage game.) This is true for any social norm that enforces cooperation in a repeated prisoner's dilemma. Examples include solutions to the common pool resource problem, ${ }^{98}$ such as water rights in India ${ }^{99}$ and land use in Estonia; ${ }^{100}$ exclusionary norms against members of other ethnic groups; ${ }^{101}$ and norms against price undercutting in the investment-banking industry. ${ }^{102}$ Prisoner's dilemma interactions in the marketplace are ubiquitous, almost by definition. A market consists of sellers and buyers, each belonging to a group that could benefit by coordination-the sellers by colluding to

96. See, e.g., Dan M. Kahan, Gentle Nudges vs. Hard Shoves: Solving the Sticky Norms Problem, 67 U. ChI. L. REv. 607 (2000).

97. See supra note 54 and accompanying text.

98. Nearly 40,000 citations to works relevant to the common pool resource problem may be found at http://dlc.dlib.indiana.edu/cpr/index.php. Illustrative examples include Douglas G. BAIRD, Robert H. Gertner \& Randal C. Picker, Game Theory and the Law 159-87 (1994) and Hirshleifer \& Rasmusen, supra note 95.

99. Bala Raju Nikku, Water Rights, Conflicts and Collective Action: Case of Telugu Ganga Project, India, in The Commons in an Age of Global Transition: Challenges, Risks and OpPortunities (The Tenth Biennial Conference of the International Association for the Study of Common Property (IASCP), Oaxaca, Mexico, Aug. 9-13, 2004).

100. Olavi Hiiemäe \& Kalev Sepp, Environmental Legislation and Property Rights in Estonia, in Commons in Transition: Property on Natural Resources in Central and Eastern Europe AND THE Former Soviet UNION (A Regional Conference of the International Association for the Study of Common Property, Prague, Apr. 11-13, 2003).

101. See, e.g., Janet T. Landa \& Xiao Tian Wang, Bounded Rationality of Economic Man: Decision Making under Ecological, Social, and Institutional Constraints, 3 J. Broeconomics 217, 228 (2001) (describing Chinese rubber dealers who would not trade with outsiders); see also Toshio Yamagishi \& Midori Yamagishi, Trust and Commitment in the United States and Japan, 18 Motivation \& Emotion 129 (1994) (finding that Japanese subjects tend to trust and trade with one another within but not across cliques).

102. Bharat N. Anand \& Alcxander Galetovic, Relationships, Competition, and the Structure of Investment Banking Markets (Harvard Business School Competition \& Strategy Working Paper No. $01-038,2000$ ) (describing a norm against price undercutting in the investment-banking industry). 
restrict output and raise prices, the buyers by collectively demanding lower prices. Whenever two or more firms may individually achieve short-term gain from breaking an agreement with a competitor but instead rely upon a social norm to enforce cooperation and enable long-term gains, the firms are interacting within a prisoners' dilemma and are agreeing to cooperate under section 1, insofar as there is evidence of norm enforcement. These enforcement mechanisms clearly fit into what antitrust law refers to as "plus factors" and ought to be very common, appearing in participant-toparticipant communications or market interactions.

To summarize, when actors sustain anticompetitive collusion in a repeated prisoner's dilemma setting, they violate the antitrust laws on the showing of plus factors. Stated more precisely, a social norm will violate the antitrust laws when (1) like any collusive practice, the effects of the norm either fit into a per se category of illegality or are, on the whole, anticompetitive; (2) the norm allows participants to cooperate away from Nash equilibria that exist in single-round versions of the participants' interaction; and (3) communication occurs between participants to enforce, or bargain, the terms of the norm. Unfortunately for participants, such communications can be used as evidence of bargaining, or as evidence of enforcement against free-riders. Verbal evidence of social enforcement may be damning in an antitrust suit, as the following case study demonstrates.

\section{IV}

NASDAQ Market Makers and the Quoting Norm

\section{A. The NASDAQ Quoting Norm}

This part describes a robust social norm among NASDAQ market makers. ${ }^{103}$ This norm specified appropriate "bid" and "ask" prices for NASDAQ stocks, with the effect of increasing the stocks' inside spreadsthat is, the difference between the highest bid price and the lowest ask price - beyond competitive levels. Between 1994 and 1996, the U.S. Department of Justice (DOJ) investigated the market makers' conduct under the antitrust laws. ${ }^{104}$ This Section summarizes the DOJ investigation and accompanying plaintiff class action suits.

Unlike the New York Stock Exchange, where dealers are given an exclusive contract to deal in a particular stock, dealers on NASDAQ competed for "order flow" against each other. ${ }^{105}$ For each stock on NASDAQ,

103. 'To 'make a market,' securities dealers-or market makers as they are known-quote a price at which they are willing to buy a particular stock, and simultaneously quote another higher price at which they are willing to sell that same stock ...." United States v. Alex. Brown \& Sons, Inc., 963 F. Supp. 235 (S.D.N.Y. I997); Stipulation and Order and Competitive Impact Statement, 61 Fed. Reg. $40,433,40,440$ (Dep't of Justice July I7, 1996) [hereinafter Competitive Impact Statement].

I04. Competitive Impact Statement, 6I Fed. Reg. at 40,439.

105. William G. Christie \& Paul H. Schultz, Why do NASDAQ Market Makers Avoid Odd-Eighth Quotes?, 49 J. FIN. 18I3, I8 I5 (I994). 
there were at least two market makers, with an average of ten to twelve market makers per national market system stock. ${ }^{106}$ These NASDAQ market makers were able to price stocks on any "eighth" of a dollar (or "point") they chose. NASDAQ security dealers made markets by buying stock at a given price (the "bid") and selling stock at a higher price (the "ask"). The NASDAQ system displayed all bid and ask prices for each stock.

The difference between an individual security dealer's bid and ask prices is that dealer's "dealer spread." The difference between the highest bid (the "inside bid") and the lowest ask (the "inside ask") among all dealers for a given stock is called the "inside spread." For a NASDAQ stock, the inside spread's bid and ask prices are the market prices for that particular stock. For example, if Salomon Brothers's bid price for Microsoft stock was $\$ 30$ and its offer price is $\$ 301 / 4$, Salomon Brothers had a dealer spread of $1 / 4$ point, or 25 cents per share. Markct maker bid and ask prices fluctuate throughout normal trading, so the inside spread at any given time could vary widely.

For a number of reasons, the size of the inside spread can affect market makers' profits. For one thing, most orders placed by individual tradcrs-customers of "retail" brokers-are market orders, meaning they can be filled at the current inside bid price (for orders to sell) or the current inside ask price (for orders to buy) ${ }^{107}$ With a wider inside spread, the market maker is thus able to charge retail buyers more and to pay less for its own purchases from retail sellers. Moreover, the inside spread can affect the negotiations between large institutional traders (even if they can typically receive better prices than the going "market" prices) and market makers. ${ }^{108}$ According to the DOJ's Competitive Impact Statement,

Market makers thus have a significant interest in each others' price quotes because those quotes can either set each others' actual transaction prices or significantly affect those prices. This creates an incentive for market makers to discourage bid and ask price competition that may have the effect of narrowing the inside spread. ${ }^{109}$

In 1994, Professors William Christie and Paul Schultz published a study describing the behavior of NASDAQ dealer firms (the "Christie/Schultz study")..${ }^{10}$ Though dealer firms could price stock on any eighth they chose, the Christie/Shultz study found that odd-eighth quotes were "virtually nonexistent" among 100 of the most active stocks in

106. United States v. Alex. Brown \& Sons, lnc., 963 F. Supp. 235 (S.D.N.Y. 1997); Competitive Impact Statement, 61 Fed. Reg. at 40, 440.

107. Competitive Impact Statement, 61 Fed. Reg. at $40,440$.

108. Id

109. Id. at $40,440-41$

110. Christie \& Schultz, supra note 105. 
1991. ${ }^{111}$ This, in effect, guaranteed a minimum inside spread of 25 cents per share for these stocks.

The Christie/Shultz study prompted a DOJ antitrust investigation and several class action lawsuits. ${ }^{12}$ The DOJ argued that the parallel behavior of avoiding odd-eighth quotes observed in the Christie/Schultz study resulted from a powerful social norm among NASDAQ traders. The DOJ defined the norm as a "two-part 'quoting convention"": (1) "if a market maker's dealer spread in a stock is $3 / 4$ point ( 75 cents) or wider, the market maker is required to quote its bid and ask process in even-eighth increments;" 113 and (2) "market makers can quote bid and ask prices on Nasdaq in odd-eighth increments . . only if they have a dealer spread of less than 3/4 point." 114 Allowing odd-eighth quotes only when the dealer's spread is less than 75 cents discourages the use of odd-eighth quotes, as the risk to the dealer increases with a narrower dealer spread. ${ }^{115}$

According to the DOJ's investigation, the norm existed in the industry for at least thirty years. ${ }^{116}$ But despite performing over 350 Civil Investigative Demands and over 225 depositions, ${ }^{117}$ the investigation revealed "no evidence that the quoting convention was the result of an express agreement reached among all of the market makers in a smoke-filled room." 118

The DOJ argued that the convention violated section 1 of the Sherman Act because it constituted anticompetitive parallelism, with sufficient plus

111. Id. at 1813-14.

112. See Arthur M. Kaplan, Antitrust as a Public-Private Partnership: A Case Study of the Nasdaq Litigation, 52 CASE W. Res. L. Rev. 111 (2001).

113. Competitive Impact Statement, 61 Fed. Reg. at 40,441.

114. Id.

115. Id.

116. Id. An excerpt from one trader's testimony:

Q: And in terms of dealer spreads that were three-quarters, when the dealer spread was threequarters, market makers moved in quarter point increments for a large number of years. is that correct?

A: Traditionally, if your spread was three-quarters of a point or more, uh, you moved your market in quarter point increments.

Q: And that was because it was unprofessional to move in eighths without closing the dealer spread to a half; is that correct?

A: Yes, ma'am.

$[\cdots]$

[A]: And if the stock trades with a ... you think you'll have to trade with a three-quarter point spread. Then you should be moving your quotation in quarter point increments. And it's one of those things I can't really tell you why. It's something that I think all of us have been doing for a gazillion, G-A-Z-1-L-L-1-O-N years, eertainly for 30 years, and it has everything to do with the professional appearance of that, that marketplace.

Id.

117. Id. at 40,439 .

118. Id. at 40,441 . 
factors to infer a section 1 agreement. ${ }^{119}$ The DOJ investigation identified five plus factors: (1) market data revealed remarkable and unnatural parallelism; (2) evidence of enforcement via "intimidating" phone calls to, and refusals to deal with, security dealers who violated the convention; (3) evidence that adhering to the quoting convention would be unprofitable but for the expected parallelism of other firms; (4) evidence that firms changed their behavior in response to the Christie/Shultz study and the DOJ investigation; and (5) evidence that market makers' pricing was different in a comparable electronic trading market. ${ }^{120}$

The DOJ investigation had profound ramifications. A jury awarded one of the highest settlements ever recorded in an antitrust action to a class of over one million class action plaintiffs: $\$ 1.027$ billion. ${ }^{121}$ In addition, the defendant market makers agreed to a consent decree that prohibited adherence to the quoting norm, fixing of inside spreads, and intimidation of traders. ${ }^{122}$ The consent decree also created an invasive antitrust compliance program that required defendants to install monitoring equipment to record conversations between market makers, appoint an antitrust compliance officer to randomly and secretly listen to no less than $3.5 \%$ of the length of their total phone calls, and provide any suspect conversation to the DOJ. ${ }^{123}$

\section{B. The Quoting Norm As Section 1 Violation}

The allegedly anticompetitive agreement between the market makers is unusual in at least two respects. First, according to industrial organization theory, the market structure should make collusion nearly impossible. Following the DOJ investigation and class action lawsuits, Vanderbilt University held a conference to discuss the Christie/Shultz study and other studies sponsored by NASDAQ and the market makers. ${ }^{124}$ Dean Furbush of Economics Inc., hired by NASDAQ, stated that "the market structure makes any collusion inconceivable," given the high number of market makers (about 400) and low barriers to entry. ${ }^{125}$ Merton Miller, an economist from the University of Chicago, also hired by NASDAQ, attributed

119. See id. at $40,441-47$ (stating that the evidence found was "of the type that courts have found sufficient to establish an agreement in violation of Section 1 of the Sherman Act" and discussing the evidence in detail).

120. Id. at $40,442-48$.

121. See In re NASDAQ Market-Makers Antitrust Litig., 184 F.R.D. 506, 515 (S.D.N.Y. 1999); In re NASDAQ Market-Makers Antitrust Litig., 187 F.R.D. 465, 470 (S.D.N.Y. 1998); Kaplan, supra note 112 , at 111 .

122. See United States v. Bleznak, 153 F.3d 16, 18-19 (2d Cir. 1998), aff'g United States v. Alex. Brown \& Sons, Inc., 963 F. Supp. 235 (S.D.N.Y. 1997).

123. Id. at 19 (individuals subject to monitoring were aware of the recording system but not of the times at which they would be monitored).

124. Floyd Norris, Market Place; The Battle of the Studies: Is There Competition at Nasdaq?, N.Y. Times, Apr. 6, 1995, at D10.

125. Id. 
the parallelism to mere "clustering." 126 Allan Kleidon of Stanford Law School and Robert Willig of Princeton University, both hired by a group of market makers, echoed these comments, concluding that "it would be prohibitively difficult" to collude effectively, in part because other firms could easily enter the business and undercut the cartel. ${ }^{127}$ Second, there was no evidence that market makers bargained over the terms of the norm. The DOJ's Competitive Impact Statement admits that the investigators had no evidence of the collusive arrangement's origin, nor did they have evidence of a negotiation process leading to such an arrangement. ${ }^{128}$

Other studies, not sponsored by the litigants, have echoed the central concern of how to reconcile the apparently collusive behavior with collusion-resistant market structures. The Christie/Schultz study attributed eveneighths pricing to collusion. ${ }^{129}$ Michael Barclay identified further empirical support for the collusion hypothesis by looking at 472 stocks before and after trading on NASDAQ in order to control for stock-specific characteristics. ${ }^{130}$ Rejecting the collusion theory, Paul Godek attributed NASDAQ even-eights pricing to the practice of preferencing, where there is less incentive to compete intensely on price. ${ }^{131}$ Parjit Dutta and Ananth Madhavan offered a formal model describing how market makers might implicitly collude to raise inside spreads above competitive levels. ${ }^{132}$ This model demonstrated that implicitly collusive, supercompetitive spreads may result from Nash strategies such as independent, profit-seeking behavior. In Dutta and Madhavan's model, dealer preferencing and price matching play crucial roles in sustaining excess spreads. ${ }^{133}$ Another theoretical

126. See id. Clustering in dealer markets was first analyzed by Lawrence Harris. He argues that dealers tend to quote on certain eighths more than others primarily to lower negotiation costs. For instance, houses are normally quoted in 1,000 or 5,000 dollar increments, partly to reduce the negotiation costs of agreeing to a more precise value. Lawrence Harris, Stock Price Clustering and Discreteness, 4 REv. FIN. STuD. 389 (1991).

127. Norris, supra note 124.

128. See Competitive Impact Statement, 61 Fed. Reg. at 40,441.

129. Christie \& Schultz, supra note 105.

130. Michael J. Barclay, Bid-Ask Spreads and the Avoidance of Odd-Eighth Quotes on Nasdaq: An Examination of Exchange Listings, 45 J. Fin. EcoN. 35 (1997).

131. See Paul E. Godek, Why Nasdaq Market-Makers Avoid Odd-Eighth Quotes, 41 J. Fin. Econ. 465, 466-67 (1996) (NASDAQ market makers can "direct or 'preference' an order to any market maker who has agreed in advance to execute orders at the best quoted price, regardless of the price actually quoted by the market maker to whom the order is directed").

132. Prajit K. Dutta \& Ananth Madhavan, Competition and Collusion in Dealer Markets, $52 \mathrm{~J}$. FIN. 245 (1997).

133. See id. at 248. Section 510(c)(3) of the National Securities Markets Improvement Act of 1996 defines "prefercncing" as "the practice of a broker acting as a dealer on a national securities exchange, directing the orders of customers to buy or sell securities to itself for execution under rules that permit the broker to takc priority in execution over same-priced orders or quotations entered prior in time." Pub. L. No. 104-290, 110 Stat. 3416 (codified in scattered sections of 15 U.S.C. (1996)). On price matching, see generally Aaron S. Edlin, Do Guaranteed-Low-Price Policies Guarantee High Prices, and Can Antitrust Rise to the Challenge?, 111 HARv. L. REv. 529 (1997) (arguing that price matching policies sustain supercompetitive prices while also incurring much higher societal costs than a 
study by Kandel and Marx argued that a collusive equilibrium could have emerged despite the absence of an enforcement mechanism. ${ }^{134}$ Both the Dutta/Madhavan and Kandel/Marx studies claimed that communication between firms was unnecessary for collusion. However, Timothy Cason found that "[d]ealer communication opportunities dramatically reduce dealer competition," 135 thus increasing prospects for collusion in dealer markets. Cason concluded that "dealers can usually recognize the value of colluding to widen the bid-ask spread" and that "dealers are able to implement a collusive agreement." 136

In the end, it seems that the dealers' parallel behavior can be traced to an industry-wide social norm. The observed market behavior suggests at least tacit collusion. After the investigations, spreads did indeed narrow, and after further regulation by the SEC, spreads narrowed still further. ${ }^{137}$ If one models the decision of NASDAQ market makers as a one-shot game, ${ }^{138}$ it should take the form of a prisoner's dilemma. But instead of reaching the expected Nash equilibrium, the market makers ended up with an outcome that maximized dealer profits, which suggests norm-based collusion.

For any particular market maker, a decision in a one-shot game might look like that summarized in Figure 1. Four pairs of choices are represented in each of four boxes. In the bottom of each box is a pair of numbers, where the first number of each pair represents the utility to the individual market maker and the second number represents the utility of all other market makers. The other market makers are treated as a single player for simplicity. As shown in box (3), regardless of the behavior of other market makers, it will always be in the single-stage self-interest of an individual market maker to renege on the deal and set more attractive bid

conventional cartel, despite low barriers to entry and no explicit agreements between sellers). Other studies reject the idea that dealer preferencing and internalization increase dealer profits. See, e.g., Oliver Hansch, Narayan Y. Naik \& S. Viswanathan, Preferencing, Internalization, Best Execution, and Dealer Profits, 54 J. FiN. 1799 (1999) (finding no correlation between dealer preferencing or internalization and increased dealer spreads in London Stock Exchange stocks).

134. Eugene Kandel \& Leslie M. Marx, Nasdaq Market Structure and Spread Patterns, 45 J. Fin. ECON. 61, 62-63 (1997) (providing a model that predicts that market makers can increase profits by using only even-eighths spreads).

135. Timothy N. Cason, The Opportunity for Conspiracy in Asset Markets Organized with Dealer Intermediaries, 13 REv. Fin. STud. 385, 398 (2000).

136. Id. at 398 .

137. See Michael J. Barclay et al., The Effects of Market Reform on the Trading Costs and Depths of Nasdaq Stocks, 54 J. FiN. 1 (1999); Paul Schultz, Regulatory and Legal Pressures and the Costs of Nasdaq Trading, 13 REv. Fin. Stud. 917 (2000). But see Hendrik Bessembinder, Trade Execution Costs on NASDAQ and the NYSE: A Post-Reform Comparison, 34 J. Fin. Quantitative ANALYSis 387 (1999) (arguing that despite SEC reforms, trading costs in NASDAQ remained higher and quotation clustering occurred more often than in the NYSE).

138. There are many reasons why modeling the behavior of market makers as a singlc round interaction is highly unrealistic, but it is a common assumption when evaluating interdependence for antitnust purposes. 
and ask spreads so as to attract more business to itself. ${ }^{139}$ Other market makers possess the same incentives, so the Nash Equilibrium is shown in box (4), a level just above perfect competition.

\begin{tabular}{|c|c|}
\hline $\begin{array}{c}\text { (1) Adhere, while other } \\
\text { market makers adhere }\end{array}$ & $\begin{array}{c}\text { (2) Adhere, while other } \\
\text { market makers renege }\end{array}$ \\
10,10 & 0,15 \\
\hline $\begin{array}{c}\text { (3) Renege, while other } \\
\text { market makers adhere }\end{array}$ & $\begin{array}{c}\text { (4) Renege, while other } \\
\text { market makers renege }\end{array}$ \\
15,0 & 2,2 \\
\hline
\end{tabular}

Figure 1. One-Shot Market Maker Decision

NASDAQ market makers, however, coordinated their behavior to box (1), which is the outcome that maximized all market makers' profits. Without more evidence, such an outcome suggests collusion, but it would be insufficient for a section 1 violation without the demonstration of a plus factor. The apparently coordinated result could be merely conscious parallelism, an outcome resulting from firms' awareness of their interdependence. The market structure suggests this, for there are very low barriers to entry and low concentration of competitors.

However, the DOJ's evidence demonstrates the presence of other factors. For example, market makers actively punished reneging, ${ }^{140}$ and this punishment could quickly and accurately be observed. ${ }^{141}$ Moreover, norm adherence was viewed as correct behavior ${ }^{142}$ and the behavior was remarkably parallel. ${ }^{143}$ Viewing a market maker's decision in the light of a social norm, however, brings to light the enforcement component. A modified version of Akerlof's reputation concerns, ${ }^{144}$ for example, would yield the prediction that a particular market trader will conform to the norm when

139. It is assumed here that if one market maker prices under the quoting norm while all others adhere, such a market maker will attract enough business that the profit gained from the volume increase outweighs the profits lost from the price decrease.

140. See Competitive Impact Statement, 61 Fed. Reg., at 40,442.

141. Id.

142. Id. at $40,442-43$.

143. Id. at 40,442 .

144. See Akerlof, supra note 93. 
where:

$$
(1-\mathrm{p} 1)(\mathrm{q} 1 * \mathrm{pr} 1)-(\mathrm{p} 1 * \mathrm{r})<(\mathrm{pr} 2 * \mathrm{q} 2)
$$

pl $=$ probability of being caught

$\mathrm{q} 1=$ quantity of sales at defection price

pr1 = defection price

$r=$ reputation harm suffered if caught

pr2 = price at quoting norm level, and

$\mathrm{q} 2$ = quantity of sales at quoting norm level.

The value of reputational harm and the likelihood of being discovered and sanctioned by others will be crucial to sustaining collusion. ${ }^{145}$ In the NASDAQ case, for instance, all bid and ask prices were available to all market makers immediately. Market markers could easily discover defections from the quoting price. The reputational harm these market makers suffered when they were caught involved "peer pressure," including unpleasant phone calls and refusals to deal. ${ }^{146}$ Moreover, the only way for defection to be more profitable than adherence would be through increased sales volume, since the defection price and resulting profit is lower per individual stock sold. Other marker makers, when viewing the defection price, could quickly lower their prices in response so as to deprive the defector of any benefit. This is because such responses cut short the cost advantage before the defector could transact in the necessary volume to recoup the lower per-unit profit.

Viewing the parallel behavior of NASDAQ market makers in this way highlights the potential that social norms have to form along the lines of classic price-fixing cartels. The next Section explores possible implications of this observation.

\section{$\mathrm{V}$ \\ ImPlications of Social NoRms As Antitrust Violations}

This Section sets out a guide for analyzing social norms as antitrust violations and applies some of the lessons to the horizontal merger context. The lessons of this Comment are particularly relevant to government review of horizontal mergers because firms may escape review entirely upon a showing that the merger fits into a safe harbor. This Comment's conclusions suggests that these safe harbors may entail erroneous conceptions about markets that are least susceptible to collusion.

145. The importance of reputation is well established in economics. See, e.g., Ronald King, Reputation Formation for Reliable Reporting: An Experimental Investigation, 71 ACCT, REv. 375 (1996); Haim Mendelson, Ripoffs, Lemons, and Reputation Formation in Agency Relationships: A Laboratory Market Study (Discussion), 40 J. FIN. 820 (1985).

146. Competitive Impact Statement, 61 Fed. Rcg., at 40,441. 
I suggest the following guidelines for analyzing social norms as antitrust violations. First, characterize the market effects. If the social norm's effect is to fix prices, rig bids, or divide territory, it could be a per se section 1 violation, and the plaintiff will only have to show agreement in order to succeed. If the effect falls outside of a settled per se category, or if the defendant's procompetitive justification is compelling, then the plaintiff will have to demonstrate the market power of the norm participants and quantify the norm's anticompetitive effect. Second, analyze whether the observed conduct is a Nash equilibrium. ${ }^{147}$ If it is, then the conduct likely results from independent profit maximization rather than collusive behavior. If the conduct is not the result of a Nash equilibrium, then look for evidence of a self-enforcing social norm. At this point, there is already a possibility of a section 1 violation, because the anticompetitive result appears in the presence of an important plus factor-that is, the behavior would be unprofitable but for coordination. Because participants will often communicate among themselves to enforce the norm through social sanctioning via reputational harm, plaintiffs ought to allege such communications in their complaints and then try to find corroborating evidence during the discovery process.

These guidelines for analyzing social norms can be applied to other areas of antitrust law. For example, there are important implications to premerger analysis, which tries to determine whether a merger will affect market participants' ability to collude. ${ }^{148}$ The first step in merger analysis, after identifying the relevant product and geographic markets, is to determine market shares and concentration levels. ${ }^{149}$ One measure of market concentration used by the DOJ in merger analysis is the HerfindahlHirschman Index (HHI). ${ }^{150}$ The amount of change in HHI caused by the proposed merger effectively determines how carefully the DOJ scrutinizes that merger, ${ }^{151}$ although it considers other factors as well. ${ }^{152}$ But other factors may be more determinative of coordination than the concentration of firms in a market. For example, a market with ten firms and a low HHI

147. It is common to use a one-stage game for this purpose, despite its obvious shortcomings. This concern reflects an important plus factor: that the conduct would be unprofitable but for coordination. See Competitive Impact Statement, 61 Fed. Reg., at 40,422.

148. See generally U.S. Dep't of Justice \& Fed. Trade Comm'n, Horizontal Merger Guidelines (1992, rev. 1997) [hereinafter Horizontal Merger Guidelines] (outlining the standards and analytical framework used by the DOJ and Federal Trade Commission to evaluate horizontal mergers and acquisitions under merger law).

149. See id.

150. See generally Stephen Calkins, The New Merger Guidelines and the Herfindahl-Hirschman Index, 71 CALIF. L. REv. 402 (1983) (reporting that the DOJ's Antitrust Division was using the HHI to analyze mergers by 1982).

I51. See id.

152. See Horizontal Merger Guidelines, supra note 147, §§ 2.11, 2.22. 
might be far less competitive than a market of two firms and a high HHI. ${ }^{153}$ Though the Horizontal Merger Guidelines mention many other factors responsible for influencing the ability of firms to compete aside from concentration, nowhere are social norms discussed, nor do factors unrelated to concentration levels divert attention to a market with very low concentration levels during the review phase. ${ }^{154}$

This Comment suggests some new directions. For example, it is possible that collusive behavior becomes more likely when there are many firms of equal size than when there are few firms of different sizes that dominate. ${ }^{155}$ This is because social norms may more easily sustain collusion when players face similar incentives and have similar cost structures. ${ }^{156}$ It may also be fruitful to focus on conditions favorable to social norm emergence, such as a history of trust between competitors. ${ }^{157}$

\section{CONCLUSION}

Social norms violate the antitrust laws when they have an anticompetitive effect on the whole. This occurs (1) when a social norm sustains cooperation in a state that is not a Nash equilibrium in a single-stage game and (2) and when communication occurs between participants to enforce the norm. A case study of the NASDAQ market makers supports this argument. This Comment challenges conventional assumptions held among social norm scholars as well as industrial organization economists, with some possible implications for antitrust enforcement and litigation.

153. A high HHI indicates high market conccntration. See Calkins, supra note 150 . The ten-firm industry may be less competitive if its good is homogenous (such as coal), allowing for easier coordination, while the two-firm market competes in a market for a heterogeneous good (such as real estate). See, e.g., Horizontal Merger Guidelines, supra note I48, § 2 .I I.

154. See Horizontal Merger Guidelines, supra note I48. This statement refers to the de facto safe harbor that firms receive from certain HHI numbers. On HHI safe harbors generally, and on some suggestions for changing them, see Roy J. Epstein \& Daniel L. Rubinfeld, Merger Simulation: $A$ Simplified Approach with New Application, 69 ANTITRUsT L. J. 883, 9 I0-I2 (200I).

155. See Dutta \& Madhavan, supra note 132.

156. See generally supra Part III.

157. See Hardin, supra note 78, at 5-6; Neal Kumar Katyal, Conspiracy Theory, I12 Y ALE L.J. 1307 (2003); Christopher R. Leslie, Trust, Distrust, and Antitrust, 82 TeX. L. Rev. 5 I 5 (2004). 
